\title{
Commentary: Molecular Mechanisms of Action of FSH
}

\author{
Rossella Cannarella, Rosita A. Condorelli ${ }^{\star}$ Sandro La Vignera and Aldo E. Calogero \\ Department of Clinical and Experimental Medicine, University of Catania, Catania, Italy
}

Keywords: FSH, IGF1, IGF-1 R, gonadal function, signaling

\section{A Commentary on}

Molecular Mechanisms of Action of FSH

by Casarini, L., and Crépieux, P. (2019). Front. Endocrinol. 10:305. doi: 10.3389/fendo.2019.00305

OPEN ACCESS

Edited by:

David Gregory Mottershead, Keele University, United Kingdom

Reviewed by:

Haim Werner,

Tel Aviv University, Israe

Joseph A. M. J. L. Janssen,

Erasmus University

Rotterdam, Netherlands

${ }^{*}$ Correspondence:

Rosita A. Condorelli

Rosita.condorelli@unict.it

Specialty section:

This article was submitted to

Reproduction,

a section of the journal

Frontiers in Endocrinology

Received: 24 June 2019 Accepted: 12 August 2019

Published: 27 August 2019

Citation:

Cannarella $R$, Condorelli RA, La

Vignera S and Calogero AE (2019)

Commentary: Molecular Mechanisms of Action of FSH.

Front. Endocrinol. 10:593.

doi: 10.3389/fendo.2019.00593
We have carefully read and appreciated the recent article by Casarini and Crépieux, entitled "Molecular mechanisms of action of FSH" (1), which provides a clear and exhaustive overview of the FSH signaling pathway. The authors notably proposed a comprehensive outline of the molecular mechanisms of FSH signaling, including the cross-talk between FSH-dependent steroidogenic, life, and death signals in granulosa cells and the temporal succession across the cAMP/PKA pathway. The authors concluded that the full comprehension of the FSH-mediated signaling action is of high physiological and clinical relevance and admit that the FSH signaling pathway is not entirely deciphered.

We agree with this statement and we would like to point out that other molecules are involved in the complex role that FSH plays in the gonadal function. Particularly, insulin-like growth factor 1 (IGF1) and its receptor (IGF1R) have already been showed to act in FSH signaling in granulosa cells $(2,3)$. Similarly, we recently confirmed such evidence in porcine Sertoli cells $(4)$.

We have focused on this topic starting from the presence of oligozoospermia in a patient with chromosome 15q26.3 duplication involving the IGF1R gene (5). In-vitro and in-vivo data from both non-mammalian and mammalian species support the role of IGF1 in Sertoli cell proliferation and in germ cell proliferation and differentiation, as well as in testis differentiation (6). The expression of the Igflr has been shown to be required for FSH responsiveness (7) in granulosa cells, thus pointing out to a possible role for the IGF1R in FSH signaling pathway. The specific molecular mechanism through which a coupled G protein receptor (CGPR) such as the FSHR involves a tyrosine kinase receptor such as the IGF1R in its signaling pathway has been explored in granulosa cells (8). The authors have shown that the two receptors are linked by the same molecular pathway and the insulin receptor substrate 1 (IRS1) is the hub-linking (8).

We have recently shown the involvement of IGF1R in the FSH signaling pathway in porcine Sertoli cells. In these primary cultures, inhibition of the IGF1R affects the FSH capacity to phosphorylate target proteins (4). Similarly to FSH, IGF1 down-regulates antiMullerian hormone $(A M H)$ gene expression and protein secretion, and enhances those of inhibin B (9). Co-incubation with both IGF1 and FSH results in a higher suppression of AMH secretion compared to that obtained with FSH alone (9). This likely suggests an enhancing effect of IGF1 on FSH. Furthermore, differently from FSH, IGF1 stimulates Sertoli cell proliferation, whereas FSH was able to stimulate cell proliferation only when co-administered with IGF1 (9).

IRS1 is linked with the intracellular domain of the IGF1R and plays a role in the FSH pathway $(5,8)$. Fascinatingly, it also interacts with the intracellular domain of the insulin receptor (IR) and is involved in the pathogenesis of insulin-resistance when abnormally phosphorylated (10). This 
may point to hypothesize a possible interference in $\mathrm{FSH}$ responsiveness in patients with insulin-resistance. We found that exposure to insulin affects the FSH-induced inhibin B secretion from porcine Sertoli cells, lowering the peak of secretion, consistent with a possible interference of insulin with the FSH action (11).

In conclusion, data from both granulosa and Sertoli cells support the role of IGF1R is the FSH signaling pathway. This

\section{REFERENCES}

1. Casarini L, Crépieux P. Molecular mechanisms of action of FSH. Front Endocrinol. (2019) 10:305. doi: 10.3389/fendo.2019.00305

2. Adashi EY, Resnick CE, Hernandez ER, May JV, Knecht M, Svoboda ME, et al. Insulin-like growth factor-I as an amplifier of follicle-stimulating hormone action: studies on mechanism(s) and site(s) of action in cultured rat granulosa cells. Endocrinology. (1988) 122:1583-91. doi: 10.1210/endo-1224-1583

3. Adashi EY, Resnick CE, Hurwitz A, Ricciarelli E, Hernandez ER, Rosenfeld RG. Ovarian granulosa cell-derived insulin-like growth factor binding proteins: modulatory role of follicle-stimulating hormone. Endocrinology. (1991) 128:754-60. doi: 10.1210/endo-128-2-754

4. Cannarella R, Arato I, Condorelli RA, Luca G, Barbagallo F, Alamo A, et al. The IGF1 receptor is involved in follicle-stimulating hormone signaling in porcine neonatal sertoli cells. J Clin Med. (2019) 8:E577. doi: $10.3390 / \mathrm{jcm} 8050577$

5. Cannarella R, Mattina T, Condorelli RA, Mongiò̀ LM, Pandini G, La Vignera S, et al. Chromosome 15 structural abnormalities: effect on IGF1R gene expression and function. Endocr Connect. (2017) 6:528-39. doi: 10.1530/EC-17-0158

6. Cannarella R, Condorelli RA, La Vignera S, Calogero AE. Effects of the insulin-like growth factor system on testicular differentiation and function: a review of the literature. Andrology. (2018) 6:3-9. doi: 10.1111/andr.12444

7. Pitetti JL, Calvel P, Zimmermann C, Conne B, Papaioannou MD, Aubry F, et al. An essential role for insulin and IGF1 receptors in regulating sertoli acknowledgment is of great importance since it might help in the elucidation of apparently idiopathic form of male infertility or FSH unresponsiveness.

\section{AUTHOR CONTRIBUTIONS}

All authors listed have made a substantial, direct and intellectual contribution to the work, and approved it for publication.

cell proliferation, testis size, and FSH action in mice. Mol Endocrinol. (2013) 27:814-27. doi: 10.1210/me.2012-1258

8. Law NC, Hunzicker-Dunn ME. Insulin receptor substrate 1, the hub linking follicle-stimulating hormone to phosphatidylinositol 3-kinase activation. $J$ Biol Chem. (2016) 291:4547-60. doi: 10.1074/jbc.M115.698761

9. Cannarella R, Mancuso F, Condorelli RA, Arato I, Mongioì LM, Giacone F, et al. Effects of GH and IGF1 on basal and FSH-modulated porcine sertoli cells in-vitro. J Clin Med. (2019) 8:E811. doi: 10.3390/jcm8060811

10. Copps KD, White MF. Regulation of insulin sensitivity by serine/threonine phosphorylation of insulin receptor substrate proteins IRS1 and IRS2. Diabetologia. (2012) 55:2565-82. doi: 10.1007/s00125-012-2644-8

11. Cannarella R, Arato I, Condorelli RA, Mongioì LM, Lilli C, Bellucci C, et al. Effects of insulin on porcine neonatal sertoli cell responsiveness to FSH in vitro. J Clin Med. (2019) 8:E809. doi: 10.3390/jcm8060809

Conflict of Interest Statement: The authors declare that the research was conducted in the absence of any commercial or financial relationships that could be construed as a potential conflict of interest.

Copyright (c) 2019 Cannarella, Condorelli, La Vignera and Calogero. This is an open-access article distributed under the terms of the Creative Commons Attribution License (CC BY). The use, distribution or reproduction in other forums is permitted, provided the original author(s) and the copyright owner(s) are credited and that the original publication in this journal is cited, in accordance with accepted academic practice. No use, distribution or reproduction is permitted which does not comply with these terms. 